\title{
DRUG CONSUMPTION BY MEDICAL STUDENTS IN TEGUCIGALPA, HONDURAS
}

Juana Carolina Buchanan ${ }^{1}$

Sandra Cristina Pillon ${ }^{2}$

Buchanan JC, Pillon SC. Drug consumption by medical students in Tegucigalpa, Honduras. Rev Latino-am Enfermagem 2008 maio-junho; 16(especial):595-600

The use of drugs, in Honduras, involves $25 \%$ of college students. The most used substances include legal and recreational drugs, such as alcohol. This study aimed to identify the use of drugs and socio-demographic factors in a sample of 260 medical students. Results: Average age of 20 years old, unemployed and religious women, single, with no children. Alcohol was the most consumed drug in the last six months for recreational purposes. The following stimulants were frequently consumed: caffeine, mate herb tea, energetic drinks and Coke. Drugs like marijuana, cocaine, valium and sedatives were used in smaller proportions. The reasons reported by women were: to alleviate tiredness and improve their academic performance. The men's reasons were recreation and to alleviate psychological tension. This research has implications for the development of drugs prevention programs in universities.

DESCRIPTORS: students, medical; alcoholism / prevention \& control; substance-related disorders / prevention \& control

\section{USO DE DROGAS ENTRE ESTUDIANTES DE MEDICINA, TEGUCIGALPA, HONDURAS}

En Honduras, el uso de drogas está presente en el $25 \%$ de estudiantes universitarios. Entre las drogas de mayor consumo están las lícitas y de uso recreacional, las bebidas alcohólicas siendo las lícitas y de uso recreacional, como el caso das bebidas alcohólicas. Ese estudio tuvo como propósito identificar el consumo de drogas y los factores sociodemográficos en una muestra de 260 estudiantes de medicina. Resultados: edad media 20 años, mujeres, solteros, no tiene hijos, no trabajan, profesan religión. La droga más utilizada en los últimos seis meses es el alcohol, con consumo recreacional. Los estimulantes de consumo frecuente: la cafeína, el mate; las bebidas energizantes, la coca-cola; y las drogas ilicitas como la marihuana, la cocaína, el valium y los inductores del sueño en menores proporciones. Las razones de uso para mujeres fueron: aliviar el cansancio, mejorar el rendimiento académico; y para varones: divertirse y aliviar tensiones psicológicas. Esta investigación tiene implicaciones en el desarrollo de programas preventivos del uso de drogas en la universidad.

DESCRIPTORES: estudiantes de medicina; trastornos relacionados con sustancias / prevención \& controle; alcoholismo / prevención y controle

\section{O USO DE DROGAS ENTRE ESTUDANTES DE MEDICINA EM TEGUCIGALPA, HONDURAS}

O uso de drogas em Honduras envolve 25\% dos estudantes universitários. As drogas lícitas estão entre as de maior consumo, como no caso das bebidas alcoólicas, que são consumidas de forma recreacional. Este estudo objetivou identificar o uso de drogas e os fatores sócio-demográficos em uma amostra de 260 estudantes de medicina de ambos os sexos. Resultados: idade média 20 anos, predominantemente mulheres, solteiras e sem filhos, religiosas e que não trabalham. A droga mais utilizada nos últimos seis meses foi o álcool de forma recreacional. Os estimulantes de consumo freqüente são a cafeína e o mate, as bebidas energizantes e coca-cola. Drogas como maconha, cocaína, valium e os indutores do sono, foram encontradas em menor proporção. As razões alegadas pelas mulheres foram aliviar o cansaço e melhorar o rendimento acadêmico. Os homens alegaram diversão e alívio da tensão psicológica. Esta pesquisa tem como propósito o desenvolvimento de programas preventivos no uso de drogas na universidade.

DESCRITORES: estudantes de medicina; transtornos relacionados ao uso de substâncias / prevenção \& controle; alcoolismo / prevenção \& controle

${ }^{1}$ MPH, RN, Full Professor, Autonomous National University of Honduras, Medical Sciences School, Honduras; ${ }^{2}$ PhD, Professor, University of São Paulo at Ribeirão Preto, College of Nursing, WHO Collaborating Centre for Nursing Research Development, Brazil, e-mail: pillon@eerp.usp.br 


\section{INTRODUCTION}

The use of psychoactive drugs is considered a global problem, which affects especially young people and adolescents ${ }^{(1)}$. According to research developed around the world and in Latin America, this problem increases in the population every day, thus constituting a relevant topic for public and international health. This is the reason why health professionals assume the commitment to insist on public policies to contribute to the reduction of this problem $^{(2)}$.

Among other impacts in health in developed countries, patterns of alcohol and other drugs use are issues in particular, because of the immediate associations to health and other physical and psychosocial aspects, as they contribute to the development of diseases in the long term ${ }^{(3)}$.

International organizations acknowledge the consequences of the use of psychoactive substances, not only for the user, but also for the family, community and people close to the user. Besides, there are indications from all around the world that $8.9 \%$ of the global burden of diseases results from the consumption of psychoactive substances ${ }^{(4)}$.

Prevalence studies on alcohol, tobacco and drugs use by medical students identified a consumption increase over the years ${ }^{(5)}$. The consumption pattern occurs in an excessive way in the population of undergraduate students, with great quantities of alcohol and experimental use of illicit drugs ${ }^{(6)}$. The authors ${ }^{(5-8)}$ point out that medical students, in particular do not differ very much from other students, because they are using several drugs, even though they are aware of their potential damages.

In the United Kingdom, drug use has been systematically monitored. In 2000 , a study on the factors influencing drugs use by medical students reported that $45 \%$ make abusive use of alcohol and marihuana, which turns them into the most used drugs $^{(7)}$. The consumption of alcohol, illicit drugs and lifestyles among medical students from the second and fifth years and one year after graduating were evaluated in a longitudinal study (1995, 1998 and 1999), observing a substantial increase in alcohol consumption and experimental use of illicit drugs ${ }^{(8)}$.

This author ${ }^{(8)}$ states that the occurrence of drug abuse and the experimental use of illicit drugs is not very clear among medical students, as it seems to be a temporary phenomenon reflected in the lifestyle of young students. It is believed that this behavior will be limited by the time students get older, occupying a professional position of responsibility. On the other hand, if this does not occur, one of the concerns for the future would be the possible consequences of drug use, which can negatively influence the students' lives and their medical future, both in the family area and in the professional aspects, due to physicians' role in society, as health professionals $^{(9)}$

In recent years, research on drugs use by undergraduate students have been developed in several Latin American countries.

The Honduran Institute for the Prevention of Alcoholism, Drugs Addiction and Dependence on Medicines (Instituto Hondureño para la Prevención del Alcoholismo Drogadicción y Farmacodependencia) reported that $25 \%$ of the undergraduate student population use some kind of drug. The study was carried out at the Autonomous National University of Honduras. Among other drugs, $3.8 \%$ of the students said they have already used stimulants or pills not to sleep at least once in their lives. From the total number of students, $2.2 \%$ still consume stimulants nowadays ${ }^{(10)}$.

Studies performed in big universities of Mexico City ${ }^{(11)}$ and Bogotá(12) also show that moderate alcohol consumption is preponderant. Besides, there is evidence that men tend to consume more than women, and that their consumption is heavier. This is observed because, in the cases of dependence and consumption, risks happen mainly in men, whereas women have risks for moderate consumption and no consumption. Although these differences are maintained, women have notably increased their consumption over the last five years.

Brazil stands out in research developed in medical students. This research is supported by educational institutions and monitors the consumption of drugs in most of the medical schools in the country, mainly in the state of São Paulo. In general, results show that alcohol, tobacco, inhalants, marihuana, amphetamines and anti-anxiety drugs are among the psychoactive substances reported as most used "at least once in life". One of the studies ${ }^{(9)}$ highlights a significant number of students who already use them before going to college; however, what stands out in the study is that $61 \%$ of the students started using 
amphetamines after they started the medical course., another study on the expectations and problems of alcohol among undergraduate students states that the transition period to university was also a stage of increased vulnerability to the use of alcohol and other drugs $^{(13)}$.

American studies that evaluate the use of stimulants by undergraduate students show that $17 \%$ of men and $11 \%$ of women at university reported use of stimulants (without a medical prescription) at least once in their lives, and about $44 \%$ of the students knew someone who used this kind of drug for recreational or academic purposes. Another study with the same methodology identified that $8 \%$ of the undergraduate students had used stimulants (without a prescription) at least once in their lives and $5 \%$ used them in the last year. In both studies, stimulant users reported major use of other drugs, going to parties more frequently and presenting more adverse consequences than licit stimulant users and nonusers $^{(14-15)}$. Yet, a study developed at the Harvard Alcohol Study Institute identified that the prevalence of stimulants (without a medical prescription) varies from 0 to $15 \%$ among students, and that prevalence levels are higher in universities that have more policies for drug use control. It also identified that students use more stimulants to increase their concentration and energy, in order to handle school activities and increase their performance on academic tests ${ }^{(14-16)}$.

Medical schools ${ }^{(17)}$ not only generate stress in their students, but also forget to teach them how to handle this situation, inculcating the idea that the patient's interest comes first, while the physician's well-being is secondary, which is the essence of medical education nowadays.

By reviewing the Plan of Medical Studies ${ }^{(17)}$, the author points out that Honduras is facinga change process at the moment, in search of better conditions and alternatives for social development; a real event that increased the conceptual and practical demand posed to universities. These institutions face the challenge of preparing the human potential in medicine and nursing, at the School of Medical Sciences. The tendencies and policies design the profile of physicians in the Medical Course, among others, with a view to responding to the needs of health care users and services.

This Plan of Study ${ }^{(17)}$ indicates that the medical course lasts seven years, with theoretical- practical components, and a year of social services. According to the enrollment office of the university, during the second semester of 2005, the institution has records of 5,300 students, $63 \%$ female and $37 \%$ male, of whom 2,650 were enrolled in the first year, 568 in the second year, 607 in the third, 440 in the forth, 265 in the fifth, 280 in the sixth, 240 in rotational residency and 250 in social services.

The motive for carrying out this study in that group is due to particular characteristics of the forth and fifth years of the medical course, which present the major load and complexity of theoretical components and clinical practice in the students' learning process. These years have a high percentage of failure, with Pathology as the subject with the highest failure rates (30\%), followed by Pharmacology, Physiology and Psychology, with failure rates of $10 \%$.

This picture generated the interest in understanding this phenomenon better, in different aspects, with the purpose of developing educational and health strategies for the prevention of drugs' consumption.

The curriculum harmoniously integrates the biological, psychological, social-humanistic and administrative-program components under a common denominator of primary health care, integrating faculty members, health care professionals and researchers around the study-work axis, which has the community and hospital level as its main action field.

Understanding the factors associated to students' drug use has not been considered a fundamental factor in the prevention field. The reason for the decision to develop this study in a group of students in the forth year of the medical course was to get to know the sociodemographic characteristics involved and their relation to the consumption of drugs in the School of Medical Sciences at the Autonomous National University of Honduras, Honduras - Central America, during the second semester of 2005.

\section{OBJECTIVE}

This study aimed to identify the pattern of stimulant and tranquilizer use and the association with sociodemographic factors among students in the forth and fifth years of the medical course. 


\section{METHODOLOGY}

The present study has a cross-sectional, descriptive and exploratory design.

The study population consisted of 730 (100\%) undergraduate students enrolled in the forth and fifth years of the medical course in the second semester of 2005. The sample consisted of 260 (35.6\%) undergraduate students from the total population, 170 $(65.4 \%)$ in the forth and $90(34.6 \%)$ in the fifth year, in Tegucigalpa, Honduras.

Sample students in the forth year were taking the subjects: introduction to clinics (22), physiology (80), pharmacology (80), pathology (70) and psychology (40), whereas students in the fifth year were having: pediatrics (50), gynecology and obstetrics (40 students).

The questionnaire was built according to two pre-elaborated instruments, which aim to identify drug use in young people, and were been adapted for the present study, regarding the use of tranquilizers and stimulants. It consisted of three parts, a) sociodemographic information, b) information referring to the use of substances by relatives and $c$ ) the pattern of substance use (kind of drug, consumption frequency, use at university, acquisition of the drugs inside and outside university) in students.

The study was formally authorized by the National Ethics Committee atthe School of Medical Sciences, Autonomous National University of Honduras, according to current rules established by the educational authorities and the medical students taking part in the study.

The research was performed by the main researcher. At the time of data collection, each sample member received a Free and Informed Consent term, answered and signed this document without any pressure, assuring intimacy, anonymity and confidentiality.

Data were collected inside the classroom, previously coordinated with the responsible faculty member. The Statistical Program for Social Sciences (SPSS) v.11. was used for data analysis and tabulation.

\section{RESULTS}

The sample comprised $76 \%$ of the undergraduate students enrolled in the forth and fifth years of the medical course of UAH. These students were between 20 (minimum age) and 35 years old (maximum age). Regarding gender, there were 145 (55.8\%) women and 115 (44.2\%) men. With respect to their marital status, $95 \%$ were single, $4.2 \%$ married and $94.2 \%$ did not have children. From the total sample, $84.2 \%$ did not work and $58 \%$ were Catholic.

Table 1 - Medical students' profiles in numbers and percentage $(n=260)$

\begin{tabular}{lcc}
\hline & $\mathbf{N}$ & $\%$ \\
\hline Age Group & & \\
$\quad 20-25$ years old & 226 & 86.9 \\
Marital Status & & \\
$\quad$ Single & 249 & 95.8 \\
$\quad$ Married & 11 & 4.2 \\
Sex & & \\
$\quad$ Female & 145 & 55.8 \\
$\quad$ Male & 115 & 44.2 \\
Religion & & \\
$\quad$ Catholic & 151 & 58.1 \\
\hline
\end{tabular}

As to the consumption of alcoholic drinks, 115 (51.9\%) are abstemious and 125 (48\%) students presented some use in the last six months. Also, 77 (61.6\%) presented experimental use, 45 (36\%) moderate use and $3(2.4 \%)$ heavy use.

From the $145(100 \%)$ women in the sample, $58(40 \%)$ used alcohol, against $67(48 \%)$ out of 115 $(100 \%)$ male students. The study did not find differences between age groups in terms of the drinking habit.

The gender comparison showed that 58 (46.4\%) women and 67 (53.6\%) men said they had consumed alcoholic drinks in the last sixmonths, which indicates a slight prevalence for male students. These results are similar to other international ${ }^{(7)}$ and national ${ }^{(10)}$ studies.

Table 2 - Comparison between kind of alcohol use in the last six months and gender of medical students from Tegucigalpa, Honduras, $2005(n=260)$

\begin{tabular}{lcccccc}
\hline & \multicolumn{2}{c}{ Female } & \multicolumn{2}{c}{ Male } & \multicolumn{2}{c}{ Total } \\
& $\mathbf{N}$ & $\%$ & $\mathbf{N}$ & $\%$ & $\mathbf{N}$ & $\%$ \\
\hline Abstemious & 87 & 60 & 48 & 41.7 & 135 & 51.9 \\
Experimental Use & 38 & 26.2 & 39 & 33.9 & 77 & 29.6 \\
Moderate Use & 19 & 13.1 & 26 & 22.6 & 45 & 17.3 \\
Heavy Use & 1 & 0.7 & 2 & 1.7 & 3 & 1.2 \\
Total & 145 & 100 & 115 & 100 & 260 & 100 \\
\hline
\end{tabular}

Table 2 also indicates a significant decrease in the number of students from experimental to heavy use. In female students, these figures decrease by half from experimental to moderate use. In male students, the number decreases by one third. These facts reveal the temporary and transitive phenomenon that is occurring in the life of these students, as literature says ${ }^{(8)}$ that many of them may be trying drugs less frequently. 
Nevertheless, this may result in problems that compromise their success in the course. This factor favors specific preventive interventions among students who are presenting experimental and moderate use of drugs, so as to create awareness during their university career and avoid increased substance consumption, which could cause greater problems.

Table 3 - Comparison between religion and kind of alcohol use in medical students, Tegucigalpa, Honduras, $2005(n=260)$

\begin{tabular}{lcccccc}
\hline & \multicolumn{3}{c}{ Religions } & \multicolumn{2}{c}{ Total } \\
& \multicolumn{2}{c}{ YES } & \multicolumn{2}{c}{ NO } & & \\
& N & $\%$ & N & $\%$ & N & $\%$ \\
\hline Abstemious & 122 & 54.2 & 13 & 37.1 & 135 & 51.9 \\
Experimental Use & 66 & 29.3 & 11 & 31.4 & 77 & 29.6 \\
Moderate Use & 34 & 15.1 & 11 & 31.4 & 45 & 17.3 \\
Heavy Use & 3 & 1.3 & - & - & 3 & 1.2 \\
Total & 225 & 100 & 35 & 100 & 260 & 100 \\
\hline
\end{tabular}

When comparing alcohol use and religion, the study identified that 122 (54.2\%) are abstemious and have a religion, versus $13(37.1 \%)$ who do not have a religion and do not drink. On the other hand, 103 $(45.7 \%)$ students who have a religion consume alcohol, versus $22(62.8 \%)$ who do not have a religion and drink. The statistical relation among these variables was not significant.

Regarding the use of drugs in general, 157 $(60.4 \%)$ said they had already used drugs at least once in their lives. Caffeine (coffee or food containing caffeine) (85\%) and mate herb tea (46\%) are among the most common drugs.

The use of popular stimulants (medicaments used without a medical prescription, such as despertac, thiamine, aspirin and others) was indicated by the study in $43(16.5 \%)$ students, and $26(60.4 \%)$ of them indicated experimental use.

Ten $(3.8 \%)$ students stated that they use marihuana. Four of them do it occasionally and one uses it everyday, which indicates a dependence level. These ten students were four women and six men.

The comparison between marital status and drugs use shows that most of them are single (94.2\%) and have no children. The study identifies that, in this group, $87.3 \%$ try tranquilizers and stimulants with a statistically significant relation $(P<0.001)$; in other words, students who have no children present increased risks of trying these drugs.

The most consumed stimulant substances include caffeine (85\%), mate herb tea 120 (46.1\%), Coke $151(58 \%)$ and energetic drinks 120 (46\%).
The study did not find significant differences between gender and the use of these drugs.

With respect to the use of illicit drugs, the study found $12(4.6 \%)$ marihuana and four (1.9\%) cocaine users. As to psychoactive drugs used without a medical prescription, 10 (3.8\%) students used valium and $23(8.8 \%)$ sleeping pills; two students showed frequent moderate consumption and four presented frequent heavy use. When comparing age groups and kinds of use, it is shown that 14 (60.8\%) students are in the age groups from 20 to 25 years old and experimentally use sleeping pills ( $p<.011$ ).

This situation is similar to findings by other international and national studies, which stress that these students are aware of the drugs and their adverse effects. They also know that, when used without a medical prescription, they can lead to dependence and abuse, as well as to the development of depressive profiles and other mental disorders, besides increasing the possibilities of morbidity and mortality risks.

The consumption of popular stimulants, such as despertac, thiamine, superthiamine, coffee and aspirin, by medical students from the forth and fifth years of the course, showed that $16.6 \%$ of them consume these substances, $15 \%$ of whom are between 20 and 25 years old.

Despite their profession, students are consuming drugs. The motivations manifested by women are tiredness and the intention to improve academic performance, whereas men do it in order to alleviate psychological tensions and for recreation, with a significant difference $(p<.002)$. These results are comparable to international studies ${ }^{(15-16)}$.

Considering the use before university, 57 (21.9\%) students stated they already used these substances before going to UNAH. Among the ten students who used valium without a medical prescription, five started its use after going to university ( $\chi 2=12.3$ p.015). These data indicate that, sometimes, the first contact with drugs does not happen inside the university, as half of them had started using this substancebefore starting the medical course, results also found by another study ${ }^{(9)}$.

Nevertheless, among students who started using substances after going to university, the study found 91 students who indicated the use of alcoholic drinks, 96 energetic drinks, 17 sleeping pills, 32 popular stimulants, 6 marihuana, 2 ether, 3 amphetamine and one of cocaine. These figures are disturbing, as new experiences after going to 
university could optimize the use of alcohol and risks associated to this consumption. The entry into university is considered a critical period of increased vulnerability for the start and continuation of drug use ${ }^{(9)}$.

\section{CONCLUSIONS}

The present study revealed the most used psychoactive substances by medical students from UNAH. Alcohol was identified as the most used drug. The study also identified the use of medicaments without medical prescription, such as valium and sleeping pills, in disturbing proportions, and the use of illicit drugs (marihuana and cocaine) in smaller proportions among the medical students. The authors conclude that a substantial and disturbing number of students are making experimental and moderate use of these drugs. This situation deserves attention by several university representatives, with a view to policies for usage reduction and control in the university environment.

\section{ACKNOWLEDGEMENTS}

Acknowledgements to the Inter-American Drug Abuse Control Commission/CICAD of the SubSecretary of Multidimensional Security at the Organization of American States/OAS, the Brazilian Anti-Drugs Secretary/SENAD, faculty members at the University of São Paulo at Ribeirão Preto College of Nursing, WHO Collaborating Centre for Nursing Research Development, Brazil, to the population who participated in the studies and to the representatives from eight Latin-American countries who participated in the I and II On-Line Specialization Program for Research Capacity-Building on the Drugs Phenomenon-PREINVEST, offered in 2005/2006 by the University of São Paulo at Ribeirão Preto College of Nursing, as a distance education course.

\section{REFERENCES}

1. Pan-America Health Organization. PAHO. Health in theAmericas Vol I. Scientific and Technical Publication. Washington DC. n. 587; 2002.

2 Wright $\mathrm{M}$ da. El Fenómeno de las Drogas y la Profesión de Enfermería, Estudios en el Uso y Abuso de Drogas 2004; 13(2):5-7.

3. Sells CW, Blum RW. Morbidity and mortality among US adolescents: An overview of data and trends. American Journal of Public Health 1996; 86(44):513-519.

4. Organización Mundial de la Salud (SWZ). Neurociencia del consumo y dependencia de sustancias psicoactivas Ginebra: Organización Mundial de la Salud; 2004.

5. Millar PM, Plant M. Drinking, smoking and illicit drug use among 15 and 16 year old in the United Kingdom. Br Med J 1996; (313):394-97.

6. Chavez KAP; O'Brien B; Pillon SC. Drugs use and risk behavior in a university community. Rev Latino-am Enfermagem 2005; 13( $\mathrm{n}$ especial):1194-200.

7. Newbury-Birch $D$, White $M$, Kamali F. Factors influencing alcohol and illicit drugs use among medical Students. Drug and Alcohol Dependence, August 1999; 59 (2000):125-30. 8. Newbury-Birch D, Walshaw D, Kamali F. Drink and drugs: from medical students to dcotors Drug and alchol Depend 2001; (64):265-70.

9. Pinton FA, Boskovitz EP, Cabrera EMS. Uso de drogas entre os estudantes de medicina da Faculdade de Medicina de São José do Rio Preto, SP no ano de 2002. Arq Ciênc Saúde 2005 abr-jun; 12(2):91-6.
10. Instituto Hondureño para la Prevención del Alcoholismo, Drogadicción y Fármaco Dependencia (IHADFA). Prevalencia del consumo de drogas en estudiantes de la Universidad Nacional Autónoma de Honduras, Tegucigalpa, Honduras 2002.

11. Flórez L. Análisis de la clasificación de etapas y de las variables psicosociales mediadoras propuestas por el modelo transteórico en estudiantes universitarios de Bogotá consumidores de bebidas alcohólicas. Informe de Investigación Institucional. Bogotá: Universidad Católica de Colombia 2002

12. Mora-Ríos J. Natera G. Expectativas, consumo de alcohol y pro-blemas asociados en estudiantes de la ciudad de México. Salud Pública de México 2001; 43(2):89-96.

13. Peuker AC, Fogaça J, Bizarro L. Expectativas e beber problemático entre universitarios. Piscol: Teoría e Pesquisa. 2006 mai-agost; 22(2):193-200.

14. Hall KM, Irwin MM, Bowman KA, Frankenberger $W$, Jewett DC. Illicit use of prescribed stimulant medication among college students. Journal of American College Health 2005; (53): $167 " 74$

15. Teter CJ, McCabe SE, Cranford JA, Boyd CJ, Guthrie SK. Prevalence and motives for illicit use of prescription stimulants in an undergraduate student sample. Journal of American College Health 2005; (53): 253"62.

16. McCabe SE, Knight JR, Teter $\mathrm{CJ}$, Wechsler $\mathrm{H}$. Non-medical use of prescription stimulants among US college students: Prevalence and correlates from a national study. Addiction 2005; (99): 96"106.

17. UNAH; Facultad de Ciencias Medicas, Plan de Estudios Carrera de Medicina, Tegucigalpa, Honduras, 1998. 